\title{
Transitional justice discourse in post-conflict societies in Africa: introduction
}

\author{
Elias O. Opongo
}

\begin{abstract}
Post-conflict reconstruction has emerged as one the major issues of concern in Africa in the last three decades. Since the end of the Cold War following the fall of the Berlin Wall in 1989, many African countries embraced multiparty systems that expanded democratic spaces. With this came the claim to justice and consciousness on the need to reconstruct a new vision of the nation, a vision that is based on social cohesion. This led to calls for democratisation in a number of African countries as well as in Latin America, Eastern Europe, and, in particular, former Soviet Union countries. In Africa, the approach taken by different countries varied from elaborate transitional justice processes that involved truth commissions to national dialogue processes that called for political compromise without putting into place any formal transitional justice process.

The articles in this supplementary issue on transitional justice discourse in postconflict societies in Africa draw attention to diverse contextual issues on post-conflict reconstruction in the continent. These articles bring together divergent discourses, experiences, theorisations, and interpretations of transitional processes while calling for a new way of assessing truth-telling processes within the purview of legal frameworks, gender and cultural sensitivities, peace sustainability, and conflict resolution strategies in Africa. The articles open up debate on the extent to which transitional justice processes contribute to peace and sustainability in Africa, and what could be done to improve this important post-conflict reconstruction initiative.
\end{abstract}

Keywords: Post-conflict reconstruction, transitional justice, peacebuilding, truth telling, truth commissions.

Note on the author: Elias O. Opongo is a senior lecturer at Hekima University College and the director of the Centre for Research, Training and Publications (CRTP) at the same university. His main research interests include: transitional justice, post-conflict reconstruction, statebuilding and democracy, and religious extremism and violence. He holds a $\mathrm{PhD}$ in Peace Studies from the University of Bradford, UK, and an MA in International Peace Studies from the University of Notre Dame, USA.

ORCID ID: https://orcid.org/0000-0002-3320-7222

(C) The author(s) 2021. This is an open access article licensed under a

Creative Commons Attribution-NonCommercial-NoDerivs 4.0 Unported License 
Post-conflict reconstruction has emerged as one the major issues of concern in Africa in the last three decades. Since the end of the Cold War following the fall of the Berlin Wall in 1989, many African countries embraced multiparty systems that expanded democratic spaces. ${ }^{1}$ With this came the claim to justice and consciousness of the need to reconstruct a new vision of the nation, a vision that is based on social cohesion. ${ }^{2}$ This led to calls for democratisation in a number of African countries as well as in Latin America and in Eastern Europe, particularly former Soviet Union countries. A number of African countries that had experienced violent conflicts, such as South Africa, Liberia, Sierra Leonne, Mozambique, Ghana, Nigeria, Uganda, Tunisia, Algeria, and Kenya, among others, opened discussions in their respective countries, on how they could address the negative impacts of conflicts and associated historical injustices. ${ }^{3}$ The approach taken by all these countries varied from elaborate transitional justice processes that involved truth commissions to national dialogue processes that called for political compromise ${ }^{4}$ without putting into place any formal transitional justice process, like the case of Mozambique.

African countries had to learn from the Latin American countries like Argentina and Chile - that had already made good attempts at transitional justice processes in the 1990s and early 2000s. These pioneering truth commissions took place under the cloud of heavy military regimes that had oppressed the people, leading to killings, arbitrary arrests, and systematic human rights violations. Argentina's 'National Commission on the Disappearances of Persons', set up in 1983 by President Raúl Alfonsín, documented gross human rights violations committed by the military dictatorship against civilians. Upon receiving the report in 1984, President Alfonsín decided to open up trials against the military juntas, the first since the Nuremberg trials following World War II, and equally the first to be conducted in a civilian court. Earlier on, Bolivia, in 1982, established a 'National Commission of Inquiry Into Disappearances' following the end of the military regime. Another prominent transitional justice process was that of Chile in April 1990, that established a 'National Truth and Reconciliation Commission', being the first to use the name 'truth and reconciliation commission'. The Commission was tasked with investigating deaths and disappearances that were politically motivated under Augusto Pinochet's rule. The latter was later arrested in London, but died before the conclusion of his trial. Other commissions in Latin America included: 'The Truth Commission' in Ecuador that investigated human rights violations between 1984 and 1988; the Honduras

\footnotetext{
${ }^{1}$ Rutto \& Njoroge (200a).

${ }^{2}$ Fatić et al. (2019).

${ }^{3}$ Sriram \& Pillay (2011).

${ }^{4}$ Brankovic \& van der Merwe (2019); see also Murambadoro (2020).
} 
'Truth and Reconciliation Commission' that investigated violent actions during the 2009 coup d'état; the 'Panama Truth Commission' set up in 2000 to investigate human rights violations by the military regime; and Peru's 'Truth and Reconciliation Commission' established in July 2001 to investigate human rights violations committed between the 1980s and 1990s. In Colombia, following the peace deal between the government forces and the rebel group, FARC, in 2016, the government established a 'Commission for the Clarification of Truth, Coexistence and Non-repetition'. However, this commission has yet to achieve its goal, given the political transitions in the country and the slow nature of the implementation of the peace agreement. The challenge for transitional justice processes in these countries was that some of the military officers (or rebel leaders in the case of Colombia) were still powerful, and hence deciding on the best way forward for the country - whether trials, amnesty, or reconciliation - became a major challenge. Elsewhere, there have been different forms of truth commissions in Germany, Australia, Fiji, Nepal, New Zealand, Sri Lanka, and Taiwan.

The above examples demonstrate that different social mobilisations within a particular historical moment of transition tend to create opportune times for the institution of transitional justice processes. Hence, 'various forms of social struggle in the face of different kinds of past violations and repressive methods are, therefore, highly relevant to the development of transitional justice'. ${ }^{5}$ As such, transitional justice processes are centred on power struggles, the delicate balance between retributive and restorative justice, forgiveness and reconciliation, as well as political and institutional reforms for peace and stability.

There are four main functions that guide transitional justice processes. These functions are founded on the principles of social cohesion and nation building. First is that transitional justice documents historical injustices in order to identify the victims and perpetrators. Second, it seeks to address the grievances brought forward by the victims and witnesses in order to ensure the recovery of justice, through consideration of some forms of compensation and reparation. In pursuit of justice, it may recommend prosecution or amnesty for the perpetrators of violence. Third, transitional justice forges forgiveness and reconciliation as a way of attaining social cohesion. Fourth, transitional justice aims at institutional reforms in the executive, judicial, legislative, police, military, and economic structures of the country. To a great extent, therefore, transitional justice focuses on putting in place mechanisms that would prevent past violence from happening again, while placing emphasis on how a broken nation can heal and move forward.

${ }^{5}$ Abrão \& Torelly (2011: 30). 
The documentation of historical injustices is key to every transitional justice process. The process may not be exhaustive because some of the victims and perpetrators may be dead or untraceable. In some cases, victims, for various reasons, may not be willing to come forward and narrate their stories. The process of documentation could include formal investigations that may require a specialised security unit to help with the investigation. Unless allowed in law, a truth commission may not have the powers to investigate crimes and subpoena victims and perpetrators. In addition, truth commissions often have restricted budgets and time frames that may not allow for a thorough investigation.

Addressing grievances brought forward by the victims is an arduous task. Corroborating what the victims, witnesses, and perpetrators have narrated may not necessarily build enough evidence for prosecution. Besides, truth commissions often do not have the authority to carry out prosecutions. Hence, pursuit of justice is one of the most difficult interventions in transitional justice processes. Also, the perpetrators may still be too powerful to arrest and prosecute or even to force to appear before a truth commission. It is therefore important to apply political and social prudence before deciding on what course of action should be taken. To a great extent, prosecutions are likely to destabilise a country if the perpetrators still command political and military power. ${ }^{6}$ A compromise approach could be to offer amnesty and engage in a political dialogue process.

A forgiveness and reconciliation approach is yet another strategy that has been applied by a number of transitional justice initiatives. It involves bringing together victims and perpetrators, and initiating a formal or informal process of encounter between the two through a process of full revelation and acknowledgement of past crimes. The perpetrator may ask for forgiveness, and the victim may or may not be in a position to forgive. However, where the victim is willing to forgive, a formal process could be initiated leading to forgiveness and reconciliation. Reconciliation is a step further than forgiveness and draws the victim and perpetrator to a conversation that acknowledges the past and seeks to rebuild the lost relationship.

In order to prevent future gross human rights violations, it is important to initiate a process of institutional reforms, particularly within key arms of government. This may entail reforms of executive powers, and in legislative, judicial, and security and economic sectors. Reforms in the executive often involve reducing the powers of the executive to avoid future abuse, or giving the executive more powers to initiate prosecutions of past crimes, or both. The legislature may have the tasks of reviewing the law to prevent past abuses but also of introducing new laws that will ensure prosecution of the perpetrators. It is also important to reform the judiciary so that the judges

\footnotetext{
${ }^{6}$ Hughes et al. (2007).
} 
are left free to make independent decisions on prosecutions and the dispensation of justice. Security sector reform is crucial because some past crimes could have been carried out by the government security forces. This was the case in South Africa, Mozambique, Angola, Sierra Leone, and Liberia. Reforms in this sector will ensure professionalism and discipline within the forces, as well as accountability for any acts committed against the law. Lastly, economic reforms are meant to ensure that victims are compensated for past crimes, and that there are clear structures put in place to improve the welfare of the population, especially the poor, and especially through employment opportunities, particularly for the youth. ${ }^{7}$

The articles in this Journal of the British Academy supplementary issue on transitional justice discourse in post-conflict societies in Africa draw attention to diverse contextual issues on post-conflict reconstruction in the continent. Ibrahim Magara (2021) focuses on transitional justice process in South Sudan, the youngest nation in the world, having gained its independence in 2011. The country has been marked by protracted conflicts, and attempts towards transitional justice are seen as possible ways of attaining sustainable peace. In his article, Magara demonstrates that the key contestations in the transitional justice process in South Sudan relate to when and how the process should be initiated, and how it could be implemented. The sequencing of the transitional justice process would be important for sustainability of peace in the country, and special caution would need to be taken over whether to carry out prosecutions or not.

The article by Elias Opongo (2021) examines advocacy strategies by critical feminists and human rights groups that draw attention to diverse forms of human rights violations against women in situations of conflict; structures of exclusion of women's concerns; agency and the presence of women in truth commission processes. The author examines the different levels of integration of gender in transitional justice processes, particularly in truth commissions, and emphasises the inclusion of women as truth commissioners, a review of legal frameworks to incorporate gender-sensitive approaches to truth commission processes, and the training of the commissioners and staff of truth commissions on an assessment of violence against women. Marginalisation of women in transitional justice processes has often led to major shortfalls in achieving transitional justice objectives. ${ }^{8}$ Hence, women's inclusion is vital for sustainable peace in post-conflict societies.

The article by Susan Kilonzo (2021) focuses on women peacebuilders as silent peacemakers in the North Rift region in Kenya, and the significant influence they have had in peacebuilding efforts in that region. Kilonzo demonstrates that the failure in

\footnotetext{
${ }^{7}$ Selim \& Murithi (2011).

${ }^{8}$ Björkdahl \& Selimovic (2015).
} 
state-led transitional justice mechanisms has shifted efforts towards community-led initiatives, and women have played a particularly pivotal role in community mobilisation for peace. While women's initiatives may not be so much in the limelight, their silent peacebuilding strategies in the North Rift region in Kenya have led to conflict transformation This perspective is a pointer towards a re-examination of transitional justice processes that are often de-linked from grassroots initiatives, despite the latter's potential to sustain peace.

Muema Wambua (2021) makes an analysis of victims and interveners and how they perceive the transitional justice process in Kenya. Wambua examines the transitional justice interventions that were initiated after the 2007/8 post-election conflict, and how the mediation led by Kofi Annan resulted in the signing of the National Accord in February 2008. This achievement was a result of multisectoral initiatives to attain peace in Kenya. Wambua's field-based study focuses on the experiences and perceptions of victims and interveners in conflict transformation programmes, with the aim of evaluating the outcomes and impacts of the transitional justice interventions, as a conduit to peacebuilding and conflict transformation. The author emphasises resolution of historical injustices as a strategy for sustainable peace.

Martin Munyao (2021) makes a comparative study between Kenya and South Africa and examines the interfaith engagement in these two countries. This article highlights the challenges and gains made by transitional mechanisms in both Kenya and South Africa, and how religious leaders have played a vital role in building the social links crucial for the success of transitional justice processes. The author appeals for the inclusion of an interfaith agenda in transitional justice initiatives, as a multilevel strategy to address violent conflicts.

Benjamin Thorne (2021) focuses on witness memory at the International Criminal Tribunal for Rwanda (ICTR), with an emphasis on the interplay between liberal international criminal law and legal memory. Thorne aims at deconstructing legal witnessing and memory production at the ICTR, as a critique in legal scholarship that purports that international criminal institutions are able to produce a collective memory of mass rights violations. The article proposes a new conceptual framework based on insights from critical theory, Giorgio Agamben (witness), and Paul Ricœur (memory). This approach exposes the limitations of Western institutions in addressing past atrocities.

These articles draw together diverse discourses, experiences, theorisations, and interpretations of transitional processes while calling for a new way of assessing truth-telling processes within the purview of legal frameworks, gender and cultural sensitivities, peace sustainability, and conflict resolution strategies in Africa. The articles open up debate on the extent to which transitional justice processes contribute to peace and sustainability in Africa, and what could be done to improve this important post-conflict reconstruction initiative. 


\section{References}

Abrão, P \& Torelly, M.D. (2011), 'Democratization and Human Rights: Sharing the Latin American Experience', in International Centre for Transitional Justice (ICTJ) Transitional Justice Handbook for Latin America (São Paulo, Brazilian Ministry of Justice Amnesty Commission), 23-31.

Björkdahl A. \& Selimovic J.M. (2015), 'Gendering Agency in Transitional Justice', Security Dialogue, 46(2): 165-81. https://doi.org/10.1177/0967010614552547

Brankovic, J. \& van der Merwe, H. (eds) (2019), Advocating Transitional Justice in Africa: The Role of Civil Society (Cham, Springer International). https://doi.org/10.1007/978-3-319-70417-3

Fatić, A., Bachmann, K. \& Lyubashenko, I. (2019), Transitional Justice in Troubled Societies (London, Rowman \& Littlefield International).

Hughes, E., Schabas, W. \& Thakur, R. (2007), Atrocities and International Accountability: Beyond Transitional Justice (New York, United Nations University Press).

Kilonzo, S.M. (2021), 'Silent Peacemakers: Grass-roots Transitional Justice and Peacebuilding by Women in Kenya's North Rift Conflicts', Journal of the British Academy, 9(s2): 53-74. https://doi.org/10.5871/jba/009s2.053

Magara, I.S. (2021), 'Timing of Transitional Justice Mechanisms and the Implications for the South Sudan Peace Process', Journal of the British Academy, 9(s2): 9-33. https://doi.org/10.5871/jba/009s2.009

Munyao, M. (2021), “New Wine, Old Wineskins”: A Comparative Study of Interfaith Engagement and Transitional Justice in Kenya and South Africa', Journal of the British Academy, 9(s2): 103-125. https://doi.org/10.5871/jba/009s2.103

Murambadoro, Y. (2020), Transitional Justice in Africa (Cham, Springer International). https://doi.org/10.1007/978-3-030-48092-9

Opongo, E.O. (2021), 'Gendering Transitional Justice Processes in Africa: A Feminist Advocacy Approach to Truth Commissions', Journal of the British Academy, 9(s2): 35-52. https://doi.org/10.5871/jba/009s2.035

Rutto, S.K. \& Njoroge, G.K. (2001), The Democratization Process in Africa (Nairobi, Quest \& Insight).

Selim, Y. \& Murithi, T. (2011), 'Transitional Justice and Development: Partners for Sustainable Peace in Africa?', Journal of Peacebuilding \& Development, 6(2): 58-72. https://doi.org/10.1080/15423166.2011.141478175834

Sriram, C.L. \& Pillay, S. (eds) (2011), Peace Versus Justice? The Dilemma of Transitional Justice in Africa (Oxford, James Currey).

Thorne, B. (2021), 'Liberal International Criminal Law and Legal Memory: Deconstructing the Production of Witness Memories at the International Criminal Tribunal for Rwanda', Journal of the British Academy, 9(s2): 127-54. https://doi.org/10.5871/jba/009s2.127

Wambua, M. (2021), 'Historical Injustices and Transitional Justice Interventions in Kenya: Victims' and Interveners' Experiences and Perceptions', Journal of the British Academy, 9(s2): 75-102. https://doi.org/10.5871/jba/009s2.075

To cite the article: Elias O. Opongo (2021), 'Transitional justice discourse in postconflict societies in Africa: introduction', Journal of the British Academy, 9(s2): 1-7. DOI https://doi.org/10.5871/jba/009s2.001

Journal of the British Academy (ISSN 2052-7217) is published by The British Academy, 10-11 Carlton House Terrace, London, SW1Y 5AH www.thebritishacademy.ac.uk 
